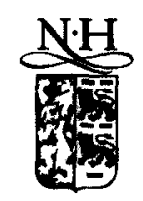

ELSEVIER

Journal of Financial Economics 39 (1995) 105-130

\title{
Executive pay and performance Evidence from the U.S. banking industry
}

\author{
R. Glenn Hubbard*, Darius Palia
}

Columbia Business School, Columbia University, New York, NY 10027, USA

(Received March 1993; final version received December 1994)

\begin{abstract}
This paper examines CEO pay in the banking industry and the effect of deregulating the market for corporate control. Using panel data on 147 banks over the 1980s, we find higher levels of pay in competitive corporate control markets, i.e., those in which interstate banking is permitted. We also find a stronger pay-performance relation in deregulated interstate banking markets. Finally, CEO turnover increases substantially after deregulation. These results provide evidence of a managerial talent market - one which matches the level and structure of pay with the competitiveness of the banking environment.
\end{abstract}

Key words: Pay; Performance; Corporate control; Deregulation; Banks JEL classification: G32; G38; G21

\footnotetext{
${ }^{*}$ Corresponding author.

We thank Franklin Edwards, Jordi Gali, William Greene, Kevin Hassett, Charles Himmelberg, Edward Kane, Frank Lichtenberg, Richard Lyons, Sam Peltzman, Elizabeth Strock, Jake Thomas, Michael Weisbach, and seminar participants at the American Economic Association meetings, Washington, DC, 1995, Boston College, Columbia University, City University of New York, and Georgetown University for their helpful discussions or comments. We are particularly grateful to the editors of this Journal (especially Michael Jensen) and Kevin Murphy (the referee) whose comments have considerably improved the paper. We thank Carlene Palia, Jeffrey Heisler, and Takeshi Furukawa for their research assistance, and Chris James for providing us with some data. All errors remain our responsibility. Hubbard acknowledges support from the John M. Olin Visiting Professorship at the Center for the Study of the Economy and the State of the University of Chicago and the Federal Reserve Bank of New York, and Palia acknowledges support from the Faculty Research Fund of the Graduate School of Business, Columbia University.
} 


\section{Introduction}

Beginning with seminal works by Berle and Means (1932) and Jensen and Meckling (1976), researchers have addressed the agency costs generated by the separation of ownership and control. Many devices have been suggested to improve the alignment of managers' incentives with the interests of shareholders, including such devices as high corporate leverage (Jensen, 1986), more effective monitoring by the board of directors (Hermalin and Weisbach, 1988; Shleifer and Vishny, 1988; Weisbach, 1988), and managerial pay.

Managerial pay (more specifically, chief executive officer pay) has come under increasing scrutiny in the popular press. On one side of the debate are critics who suggest that chief executive officer (CEO) pay is not related to performance and is frequently 'excessive'. Suggestions have ranged from capping CEO pay to making pay a prescribed multiple of the lowest worker's salary. On the other side of the debate are proponents of moderate reform of the current executive compensation system. For example, in a recent article in Business Week, Peter T. Chingos, a compensation consultant at KPMG Peat Marwick, comments that high pay reflects the limited number of executives who can run large organizations successfully, stating (March 30, 1992, p. 56):

'We're reaching hysterical levels of concern. It's more of a knee-jerk reaction and a paranoia. There are clear examples of abuses out there... but they make up only a small minority... How many Michael Eisners are there in the world? Companies have to pay a premium for business luminaries.'

In this paper, we study the banking industry to determine whether CEO pay is excessive or necessary to attract the requisite managerial talent.

Chief executive officer pay has been examined empirically by Jensen and Murphy (1990a), Murphy (1985, 1986), Rosen (1990), Barro and Barro (1990), Joskow, Rose, and Shepard (1993), Crawford, Ezzell, and Miles (1993), Houston and James (1992), and Rose and Shepard (1994), all of whom find a positive relation between pay and performance for samples of publicly-held corporations. Jensen and Murphy (1990a) examine the link between changes in shareholder wealth and CEO pay and find a significant positive relation between pay and performance. However, they find only a $\$ 3.25$ change in CEO wealth per $\$ 1,000$ change in shareholder wealth. They attribute this small sensitivity to public and private political forces influencing the managerial compensation market, noting that managerial compensation is highly visible and attracts 'implicit regulation' that truncates the upper tail of managerial compensation. Murphy (1985) also finds a positive relation between pay and performance, whereas Murphy (1986) finds that the pay-performance sensitivity is negatively influenced by CEO experience. These results are confirmed by Barro and Barro 
(1990) using a sample of commercial banks. Joskow, Rose, and Shepard (1993) examine the differences in CEO pay between regulated firms (not including banks) and unregulated firms; they find that regulated firms have lower levels of CEO pay while offering compensation packages that are less sensitive to CEO performance. Smith and Watts (1992) compare regulated and unregulated firms and find evidence that firms with greater investment opportunities employ more skilled executives who have to be given both a higher level of pay and a more pronounced pay-performance relationship. Houston and James (1992) compare banks with nonbanking firms and find no evidence of greater pay-performance sensitivity in banks than in nonbanking firms. In addition, they find that banks are less reliant on managerial stock options and ownership than nonbanking firms, with no differences in CEO turnover rates between banking and nonbanking firms. Accordingly, these authors suggest that the compensation arrangement does not reward bank CEOs for exploiting risk-taking opportunities caused by the fixed-rate deposit insurance contract historically offered by the Federal Deposit Insurance Corporation.

Most previous academic research has examined CEO pay in industrial firms. Only Barro and Barro (1990), Crawford, Ezzell, and Miles (1993), and Houston and James (1992) analyze CEO pay in commercial banks. ${ }^{1}$ This paper extends existing studies by examining the effect of the market for corporate control on both the level and structure of CEO pay in commercial banks. Banking is one industry in which some variations of the corporate control market can be easily identified. In particular, the corporate control market for banks is defined by the regulations legislated by each state, and is largely influenced by whether banks from other states are allowed to compete in local banking markets. Historically, most states did not allow mergers or any sort of branching activity across states, and the McFadden Act of 1927 required national banks to conform to state branching restrictions. Interstate banking became more widespread in the 1980 s, when a number of states broadened the boundary restrictions that had originally been imposed on the industry. Interstate banking legislation introduced in many states allowed local banks to be acquired by out-of-state banks. This change effectively made the bank market for corporate control more competitive by reducing or eliminating geographical restrictions along county or state lines.

\footnotetext{
${ }^{1}$ Crawford, Ezzell, and Miles (1993), henceforth CEM, specifically examine whether bank CEO pay is more sensitive to performance after deregulation. However, CEM simply define 1976-1982 as a 'regulated' period and 1982-1988 as a 'deregulated' period, whereas our analysis incorporates the actual year in which the specific deregulation of interstate banking legislation occurred for each bank. In addition, our sample of 147 banks is much larger than CEM's sample of 37 banks. Finally, we examine whether the level and structure of CEO pay is affected differently for a sample of banks with no CEO changes; CEM make no such distinction.
} 
We examine whether a more competitive environment requires greater management skills in CEOs. We use interstate bank regulation as a proxy for the extent of competition in markets in which banks operate. Analyzing the effects of the changes in regulation on the level and structure of CEO pay is analogous to examining whether talented managers in more competitive markets are appropriately rewarded. The managerial talent hypothesis suggests that less strict interstate regulation leads to a higher level of potential competition, requiring a more capable CEO and, therefore, higher and more responsive pay. We restrict our analysis to one form of regulation, namely, interstate banking restrictions, that put pressure (via the market for corporate control) on a manager's need to perform. The interstate regulation data exhibit both cross-sectional and time-series variation in our sample of banks, allowing us to test whether changes in regulation during the 1980 s influence both the level of pay and the strength of the pay-performance relationship. We also test whether CEO turnover increases after interstate banking legislation is introduced.

In an important paper, Jensen and Murphy (1990a) eliminate the implicit heterogeneity among firms in panel data, using first differences to examine the relation between pay and performance. To analyze the effects of regulation, we control for bank-specific omitted variables by allowing each bank to have a separate intercept term. To estimate such a 'fixed effects' model, each observation is differenced from the mean for that variable. These deviations from individual means are then used in the regressions. For example, deviations from mean shareholder wealth are regressed on deviations from mean pay. The fixed effects estimators are obtained from these regressions. [For a more detailed explanation of the econometric approach, see Greene (1993) or Hsiao (1986).] Given that most of the sample had restrictive interstate banking laws at the beginning of our sample period but had deregulated by the end of our sample period, we estimate our models both with and without year dummies. We find that CEO pay and performance (measured by shareholder wealth) are positively related in our sample of commercial banks, supporting the view that a more competitive environment requires a $\mathrm{CEO}$ with higher talent who has to be given higher levels of pay. Further, we find that the pay-performance relationship is stronger in competitive markets than in markets where interstate banking is not permitted. We also find that CEO turnover increases substantially after deregulation. Taken together, these results suggest that interstate banking deregulation affects both the level and structure of CEO pay in a manner consistent with the managerial talent hypothesis.

However, these results do not differentiate between banks with the same CEO during the sample period and banks that had different CEOs during the sample period. Accordingly, we examine a subsample of banks that had the same CEO during the entire sample period to ensure that the change in a new CEO's compensation and equity holdings from that of his or her predecessor has no 
significant impact on our results. We find that the sample of banks with CEO changes experiences larger changes in pay levels after deregulation than the sample of banks with no CEO changes, with pay defined as salary, bonus, and options. However, the percent of bank equity held by the CEO increases significantly under deregulation when the CEO is an incumbent, but decreases significantly under deregulation when the CEO is new, possibly because new CEOs have smaller equity holdings than their predecessors.

The paper is organized as follows. Possible effects of interstate regulation on the level of pay and on the pay-performance relationship are explained in Section 2. In Section 3, we describe our definitions of pay, equity holdings, performance, and bank size. Section 4 describes our data, and the estimation strategy and variables used in the analysis. Our empirical tests and results are presented in Section 5. Section 6 concludes.

\section{The effect of interstate regulation on the level of CEO pay and the pay-performance relationship}

Banking is an industry in which regulation plays a major and relatively easily identified role (see, e.g., the general discussion in Hubbard, 1994, Ch. 14). We focus on interstate banking, an important component of bank regulation. Geographic restrictions on expansion by banks, particularly across state lines, have long been part of the U.S. banking system. The McFadden Act of 1927 defined banking markets as statewide by allowing national banks to branch within the geographical limits permitted to state chartered banks. However, some banks overcame these restrictions with the use of multibank holding companies. The Douglas Amendment to the Bank Holding Act of 1956 plugged this loophole by specifying that the Federal Reserve Board could not approve an application by a bank holding company (BHC) to acquire $5 \%$ or more of the voting shares of interest in all, or substantially all, of the aspects of any bank located outside of the holding company's home state [Title 12 US Code Section 1842 (d)]. To avoid conflicts with states' rights, the Douglas Amendment allowed a BHC to acquire a bank located outside its home state provided the target bank's state specifically allowed it.

The state boundary restriction for bank expansion has changed considerably since 1980 , with a number of states ( 49 out of 50 prior to the passage of the Riegle-Neal Interstate Banking Act in September 1994) passing some type of interstate banking law (i.e., exploiting the states' rights loophole of the Douglas Amendment). In June 1985, interstate acquisition and mergers were fully legitimized when the Supreme Court ruled in Northeast Bancorp v. Board of Governors that 'state statutes ... comply with the Douglas Amendment and they do not violate ... clause(s) of the U.S. Constitution'. According to this ruling, a state could say nothing and thus prevent entry by any out-of-state BHCs or it 
could specifically allow out-of-state BHCs to acquire or establish in-state banks to the same extent as could in-state BHCs. Thus, each state had to choose its de novo entry and acquisition regulations. With this case, more states passed interstate banking laws. Prior to the recently passed interstate banking legislation, a number of states belonged to what is referred to as interstate regional compacts. A few states had reciprocal relationships with other states in a given region, while some allowed national entry or had a specified date after which nationwide entry was permitted.

We assume that allowing interstate banking greatly increases the number of participants in the bank's corporate control market, resulting in a more competitive banking environment. Under the managerial talent hypothesis, more competitive markets require managers with greater skills or talent. Takeovers are credible disciplining devices that prevent poorly performing managers from entrenching themselves and increasing their pay above competitive levels. Banks in states where interstate banking is permitted attract managers who can perform with the 'credible threat' mechanism of a competitive, well-functioning corporate control market. Accordingly, a higher level of pay is required to attract more talented managers to the more competitive environment (see, e.g., the discussion in Peltzman, 1993). ${ }^{2}$ If the managerial talent required in the two environments were the same, one would observe a migration of CEOs from the more regulated environment (with lower levels of pay) to the less regulated environment (with higher levels of pay). We find no evidence that this migration occurred in our sample. In addition, CEOs in a more competitive banking environment have to perform or be fired. Consequently, CEO turnover should increase with the increase in competition following a state's deregulation. Banks would have to increase their managerial talent commensurate with their new operating environment.

Deregulating interstate banking will also affect the structure of managerial pay under the managerial talent hypothesis. For example, Jensen and Murphy (1990b, p. 44) explain that 'a highly sensitive pay-for-performance system will cause high-quality people to self-select into a company'. According to this argument, a CEO in a less regulated environment will have a pay contract structured to provide a more significant component of his or her remuneration from performance-based pay. Such a compensation scheme allows the talented manager operating in the competitive environment to be better paid when he or she performs well. Consequently, one would expect the talented manager to have his or her compensation include a greater number of stock options. In

\footnotetext{
${ }^{2}$ It is possible that differences in the level of pay and the pay-performance relation between firms in regulated and unregulated industries reflect political constraints on pay (as argued, e.g., by Joskow, Rose, and Shepard, 1993). It is, in general, difficult to distinguish this explanation from the managerial talent hypothesis (see also Peltzman, 1993) that regulated and unregulated firms compete for CEOs of different abilities.
} 
addition, with the greater possibility that CEO actions can enhance profitability, the talented manager in markets in which interstate banking is permitted may prefer to have his or her wealth more strongly tied to performance than a manager in markets in which interstate banking is not permitted. Consequently, one may expect CEOs in markets in which interstate banking is permitted to have higher equity holdings in their bank than CEOs in markets with no interstate banking laws.

The implication of a weaker pay-performance relationship in markets with restrictive interstate banking regulation implicitly assumes that managerial contracts are not optimal in the more regulated environments. If the contracts were optimal, deregulation of the restrictive corporate control market would decrease the need for a strong pay-performance relationship to align managerial and shareholder interests because the corporate control markets would substitute for strong pay-performance sensitivities. What permits suboptimal labor contracts to exist in these regulated environments? One possibility is that CEOs in restricted banking markets are subject to closer supervision by their state banking regulators. This constant regulatory oversight might hinder CEOs from raising their levels of pay even when the bank performs well. In addition, restrictive interstate banking legislation might be highly correlated with other measures of regulatory supervision by the state banking authorities such as required levels of community lending, etc. Consequently, our measure of CEO performance - creation of shareholder wealth - is not necessarily the sole metric by which banking regulators evaluate CEOs. Stockholders who privately prefer an optimal compensation scheme might be willing to compromise it to obtain reduced regulatory stringency in other areas. However, we do not test explicitly for these possibilities, and only propose them as potential reasons for a weaker pay-performance relationship under regulation.

However, aligning CEO pay with bank performance introduces additional risk in the compensation contract. One might then argue that managers in restrictive banking environments do not have much risk in their contract (since they have a lower sensitivity to pay) and, therefore, have lower levels of pay. We estimate the standard deviations of bank returns before and after interstate banking deregulation and find no significant differences. Risk-averse managers would, however, prefer to have their compensation contracts made less sensitive to performance in the riskier interstate banking environment. This argument suggests an inverse relationship between the risk of the banking environment and the risk of the CEO's compensation. Accordingly, CEOs in deregulated banking markets would prefer to have a diminished pay-performance sensitivity under this risk-differential hypothesis, in contrast to the higher pay-performance sensitivity suggested by the managerial talent hypothesis. We provide evidence on this risk-differential hypothesis in Section 5. 


\section{Defining pay, equity holdings, performance, and size}

\subsection{Pay}

There are many mechanisms by which compensation policy provides valueincreasing incentives to improve a CEO's performance. These mechanisms can be classified into performance-based bonus and salary, stock options, and performance-based dismissal actions. We employ two definitions of CEO pay. Our first definition includes the dollar value of a CEO's salary and bonus in the current year only. Given that CEO equity ownership is not under the direct control of the compensation committee, we do not include stock ownership in examining changes in the level of CEO pay. The second definition of pay includes the dollar value of a CEO's salary and bonus in the current year and the value of stock options granted.

To value the stock options, we use the Black-Scholes (1973) option valuation model assuming continuously paid dividends (Noreen and Wolfson, 1981; Murphy, 1985; Jensen and Murphy, 1990a). The dollar value of the options is calculated as

$$
N\left[S^{*} \Phi\left(Z^{*}\right)-X \mathrm{e}^{-r T} \Phi\left(Z^{*}-\sigma \sqrt{T}\right)\right],
$$

where

$$
S^{*}=S-D \mathrm{e}^{-r T}, \quad Z^{*}=\frac{\ln \left(S^{*} / X\right)+\left(r+\sigma^{2} / 2\right) T}{\sigma \sqrt{T}} .
$$

$N$ is the number of options granted in the current year at exercise price $X$. We assume that each option has a ten-year maturity (as in Houston and James, 1992). $S^{*}$ is the year-end stock price net of the present value of dividends paid, and $D$ is the annual dividend paid. We also calculated $S^{*}$ using stock prices on the date the options were granted when that date was available from the bank proxy statements, but there were no significant differences in our empirical results. We estimate $\sigma$, the standard deviation of stock returns in the previous twelve-month period, and use the interest rates on the constant-maturity tenyear Treasury bonds in year $t$ as the relevant risk-free rate $r_{t} . \Phi(\cdot)$ is the cumulative standard normal distribution function.

Regarding performance-based dismissal actions, studies such as Coughlan and Schmidt (1985), Warner, Watts, and Wruck (1988), Weisbach (1988), Jensen and Murphy (1990a), and Murphy and Zimmerman (1991) have found a negative relationship between net-of-market firm performance and the probability of managerial turnover. These findings suggest that managers are more likely to leave after bad years than after good years and are disciplined by the credible threat of dismissal. As this issue is not the focus of our study, we do not include the threat of dismissal in our definition of CFO pay. 


\subsection{Equity holdings}

Although equity holdings can be bought by the CEO independent of the direct shares he or she is given by the compensation committee, equity ownership does align incentives between CEOs and their shareholders, allowing us to create a definition of CEO wealth invested in the firm that includes equity holdings. We use this definition when we examine the pay-performance relationship; in particular, we use year-end stock prices to compute the value of equity that a CEO holds in the bank. Hence, we calculate the percentage of equity held by the CEO in the bank as our measure of CEO equity holdings.

\subsection{Performance}

Problems between principals and agents suggest that managerial pay should be related to managerial actions in order to align the insurance motive of the manager with the wealth-maximizing incentive of the shareholder. Consequently, market movements that have little to do with a manager's actions should be excluded from his or her performance measure. On the one hand, relative performance appears to be a significant determinant of pay, as shown by Coughlan and Schmidt (1985), who find a positive relation between pay and net-of-market returns, and by Gibbons and Murphy (1990), who find a negative relation between average industry returns and pay. On the other hand, Antle and Smith (1986), Murphy (1985), and Barro and Barro (1990) find that relative performance does not matter. Given that we examine a sample of commercial banks, in which market movements probably affect the sample uniformly, we analyze measures of performance using individual bank returns only.

Although there is little doubt that CEO pay is related to performance, a debate has arisen as to whether stock market returns or accounting returns are more informative for executive incentives. Whereas Jensen and Murphy (1990a) and Murphy (1985) confine their definition of performance to stock returns (and different transformations thereof), some studies use accounting numbers as the relevant measure of performance (see, e.g., Kostiuk, 1989). Given the potential for misrepresentation in accounting numbers and the inherent overstatement of value (particularly in the book-value accounting of bank loans) in a commercial bank's balance sheet, we restrict our analysis to stock market measures.

\subsection{Size}

A number of empirical studies (see Ciscell and Carroll, 1980, for a survey) have found a positive relation between firm size and pay, motivating theoretical studies dating back to Simon (1957) and more recently to Rosen $(1982,1990)$. Rosen analyzes the firm as a hierarchical control structure with the CEO at the 
top: the CEO's every action multiplies over his or her 'scale of operations', allowing him or her to accrue rents in a competitive equilibrium. Consequently, a competitive labor market allocates more talented senior executives to larger firms since the marginal productivity of their actions is magnified across the lower levels of the hierarchy. This hypothesis suggests a positive relation between firm size and pay levels. However, because of the potential correlation between firm size and performance, many studies (e.g., Jensen and Murphy, 1990a; Murphy, 1985, 1986) do not include size in their set of regressors. [This is discussed at some length in Ciscell and Carroll (1980) and Dunlevy (1985).] We include size as a control variable in our reduced-form models to examine whether more rapidly growing banks have CEOs with higher levels of pay. Using deviations from mean asset size captures the growth in asset size. We also test whether our estimated fixed effects are correlated with a bank's asset size.

\section{Data sources, estimation strategy, and variables}

\subsection{Data description}

We obtain data for the compensation variables from the annual proxy statements filed by banks with the Securities and Exchange Commission for the years 1980-1989. These compensation data are then matched with bank performance data. Each bank's yearly stock return is calculated from the Center for Research in Security Prices (CRSP) stock return file, and all other bank-specific data (e.g., asset size, annual dividends paid) are from Standard and Poor's Bank Compustat. We obtain the 1980 to 1989 interest rates on ten-year constantmaturity Treasury bonds from the 1993 Economic Report of the President. We select a longitudinal sample in order to examine banks that were publicly traded and had compensation data available for a number of years. The final sample consists of 147 banks, most of which have ten years of complete data (1980-1989); see Table 1. More specifically, we have 1,202 bank CEO data points, as data for a few banks is missing for some years. The dummy for bank regulation was created using information from Golembe and Holland (1986) and Amel (1991), who list the characteristics of each state's interstate bank regulation. We convert their description into a dummy variable based on the restrictiveness of the legislation. All monetary variables are expressed in constant (1989) dollars. These 147 banks are from 36 different states plus the District of Columbia and capture substantial time variations in the interstate banking variable.

\subsection{Estimation strategy and variables}

In examining the level of CEO pay, we test whether the dollar value of salary, bonus, and options increase after interstate banking deregulation. We use the 
Table 1

Banks in the sample, the state in which they are located, and the year the state changed its interstate banking legislation

\begin{tabular}{|c|c|c|}
\hline Name of bank & State & Year \\
\hline Affiliated Bancshares Colorado Inc. & Colorado & 1988 \\
\hline Ameritrust Corp. & Ohio & 1985 \\
\hline Amsouth Bancorp & Alabama & 1987 \\
\hline Arizona Commerce Bank & Arizona & 1986 \\
\hline B B \& T Financial Corp. & N. Carolina & 1985 \\
\hline BSD Bancorp & California & 1987 \\
\hline Baltimore Bancorp & Maryland & 1985 \\
\hline Banc One Corp. & Ohio & 1985 \\
\hline BancOklahoma Corp. & Oklahoma & 1987 \\
\hline Bancorp Hawaii Inc. & Hawaii & 1988 \\
\hline BancTexas Group South & Texas & 1987 \\
\hline Bank of Boston Corp. & Massachusetts & 1983 \\
\hline Bank of New England Corp. & Massachusetts & 1983 \\
\hline Bank of New York Inc. & New York & 1982 \\
\hline Bank of San Francisco Holding Co. & California & 1987 \\
\hline Bank South Corp. & Georgia & 1985 \\
\hline BankAmerica Corp. & California & 1987 \\
\hline Bankers Trust & New York & 1982 \\
\hline Barnett Banks Inc. & Florida & 1985 \\
\hline Bay Banks Inc. & Massachusetts & 1983 \\
\hline Boatmens Bancshares Inc. & Missouri & 1986 \\
\hline C B \& T Bancshares & Georgia & 1985 \\
\hline C V B Financial Corp. & California & 1987 \\
\hline Central Fidelity Banks Inc. & Massachusetts & 1983 \\
\hline Chase Manhattan Corp. & New York & 1982 \\
\hline Chemical Banking Corp. & New York & 1982 \\
\hline Citicorp & New York & 1982 \\
\hline Citizens First Bancorp & New Jersey & 1986 \\
\hline Citizens Trust Bank & Virginia & 1985 \\
\hline Citizens \& Southern Corp. & Georgia & 1985 \\
\hline City National Corp. & California & 1987 \\
\hline City Trust Bancorp & Connecticut & 1983 \\
\hline Colorado National Bancshares & Colorado & 1988 \\
\hline Comerica Corp. & Michigan & 1986 \\
\hline Commerce Bancshares & Missouri & 1986 \\
\hline Commercial Bancshares Inc. & New Jersey & 1986 \\
\hline Community Nat'l Bank \& Trust & New York & 1982 \\
\hline Continental Bancorp & Illinois & 1984 \\
\hline Corestates Financial Corp. & Pennsylvania & 1986 \\
\hline Crestar Financial Corp. & Virginia & 1985 \\
\hline Cullen Frost Bankers Inc. & Texas & 1987 \\
\hline Dauphin Deposit Corp. & Pennsylvania & 1986 \\
\hline Deposit Guaranty Corp. & Mississippi & 1988 \\
\hline Dominion Bancshares & Virginia & 1985 \\
\hline
\end{tabular}


Table 1 (continued)

\begin{tabular}{|c|c|c|}
\hline Name of bank & State & Year \\
\hline Eldorado Bancorp & California & 1987 \\
\hline Equimark Corp. & Pennsylvania & 1986 \\
\hline Equitable Bancorp & Maryland & 1985 \\
\hline Fifth Third Bancorp & Ohio & 1985 \\
\hline First Alabama Bancshares & Alabama & 1987 \\
\hline First $\Lambda$ merican Corp. & Tennessee & 1985 \\
\hline First Bancorp of Ohio & Ohio & 1985 \\
\hline First Bank Systems Inc. & Minnesota & 1986 \\
\hline First Chicago Corp. & Illinois & 1984 \\
\hline First Citizens Bancshare Inc. & N. Carolina & 1985 \\
\hline First City Bancorp Texas Inc. & Texas & 1987 \\
\hline First Commerce Corp. & Louisiana & 1987 \\
\hline First Empire State Corp. & New York & 1982 \\
\hline First Federal Bank & Alabama & 1987 \\
\hline First Fidelity Bancorp & New Jersey & 1986 \\
\hline First Florida Banks Inc. & Florida & 1985 \\
\hline First Hawaiian Inc. & Hawaii & 1988 \\
\hline First Interstate Bancorp & California & 1987 \\
\hline First Maryland Bancorp & Maryland & 1985 \\
\hline First National Cincinnati Corp. & Ohio & 1985 \\
\hline First National Corp. & California & 1987 \\
\hline First of America Bancorp & Michigan & 1986 \\
\hline First Pennsylvania Corp. & Pennsylvania & 1986 \\
\hline First Republic Bancorp & Texas & 1987 \\
\hline First Security Corp. & Utah & 1984 \\
\hline First Tennessee National Corp. & Tenncssee & 1985 \\
\hline First Union Corp. & N. Carolina & 1985 \\
\hline First Virginia Banks Inc. & Virginia & 1985 \\
\hline First Wachovia Corp. & N. Carolina & 1985 \\
\hline First Wisconsin Corp. & Wisconsin & 1987 \\
\hline Fleet Financial Group Inc. & Rhode Island & 1984 \\
\hline Florida National Banks & Florida & 1985 \\
\hline Fourth Financial Corp. & Kansas & 1989 \\
\hline Hibernia & Louisiana & 1987 \\
\hline HUBCO & New Jersey & 1986 \\
\hline Huntington Bancshares Inc. & Ohio & 1985 \\
\hline Indiana National Corp. & Indiana & 1986 \\
\hline Interchange Financial & New Jersey & 1986 \\
\hline International Bank & D. Columbia & 1985 \\
\hline J.P. Morgan \& Co. & New York & 1982 \\
\hline Key Corp & New York & 1982 \\
\hline La Jolla Bancorp & California & 1987 \\
\hline Landmark Bancshares Corp. & Missouri & 1986 \\
\hline Liberty National Bancorp & Kentucky & 1984 \\
\hline M N C Financial Inc. & Maryland & 1985 \\
\hline Manufacturers Nat'l Corp. & Michigan & 1986 \\
\hline
\end{tabular}


Table 1 (continued)

\begin{tabular}{|c|c|c|}
\hline Name of bank & State & Year \\
\hline Marshall \& Ilsley Corp. & Wisconsin & 1987 \\
\hline Mellon Bancorp & Pennsylvania & 1986 \\
\hline Mercantile Bancorp Inc. & Missouri & 1986 \\
\hline Mercantile Bancshares Corp. & Maryland & 1985 \\
\hline Merchants Bank & New York & 1982 \\
\hline Merchants National Corp. & Indiana & 1986 \\
\hline Meridian Bancorp & Pennsylvania & 1986 \\
\hline Michigan National Corp. & Michigan & 1986 \\
\hline Midlantic Corp. & New Jersey & 1986 \\
\hline Moore Financial Group & Idaho & 1985 \\
\hline Multibank Financial Corp. & Massachusetts & 1983 \\
\hline N B D Bancorp & Michigan & 1986 \\
\hline NCNB Corp. & N. Carolina & 1985 \\
\hline National Bancshares Corp. & Texas & 1987 \\
\hline National City Corp. & Ohio & 1985 \\
\hline North Fork Corp. & New York & 1982 \\
\hline Northeast Bancorp Inc. & Connecticut & 1983 \\
\hline Northern Trust Corp. & Illinois & 1984 \\
\hline Old Kent Financial Corp. & Michigan & 1986 \\
\hline P N C Financial Corp. & Pennsylvania & 1986 \\
\hline Pacific Western Bancshares & California & 1987 \\
\hline Penn Bancorp & Pennsylvania & 1986 \\
\hline Premier Bancorp & Louisiana & 1987 \\
\hline Puget Sound Bancorp & Washington & 1987 \\
\hline Rainier Bancorp & Washington & 1987 \\
\hline Republic NY Corp. & New York & 1982 \\
\hline Riggs National Corp. & D. Columbia & 1985 \\
\hline Santa Monica Bank & California & 1987 \\
\hline Seattle Bank & Washington & 1987 \\
\hline Security Pacific Corp. & California & 1987 \\
\hline Shawmut National Corp. & Connecticut & 1983 \\
\hline Signet Banking Corp. & Virginia & 1985 \\
\hline S. Carolina National Corp. & S. Carolina & 1986 \\
\hline Southeast Banking Corp. & Florida & 1985 \\
\hline Southern National Corp. & N. Carolina & 1985 \\
\hline Southtrust Corp. & Alabama & 1987 \\
\hline Southwest Bancorp & California & 1987 \\
\hline Sovran Financial Corp. & Virginia & 1985 \\
\hline Standard Federal Bank & Michigan & 1986 \\
\hline State Street Boston Corp. & Massachusetts & 1983 \\
\hline Sterling Bancorp & New York & 1982 \\
\hline Suntrust Banks Inc. & Georgia & 1985 \\
\hline Texas American Bancshares Inc. & Texas & 1987 \\
\hline Texas Commerce Bancshares & Texas & 1987 \\
\hline Toledo Trust Corp. & Ohio & 1985 \\
\hline U J B Financial Corp. & New Jersey & 1986 \\
\hline United Banks Colorado & Colorado & 1988 \\
\hline
\end{tabular}


Table 1 (continued)

\begin{tabular}{llr}
\hline Name of bank & State & Year \\
\hline United Missouri Bancshares Inc. & Missouri & 1986 \\
United States Bancorp & Oregon & 1986 \\
United States Trust Corp. & New York & 1982 \\
University Bank & Massachusetts & 1983 \\
Valley National Corp. & Arizona & 1986 \\
Wells Fargo \& Co. & California & 1987 \\
West America Bancorp & California & 1987 \\
Westlands Diversified Bancorp & California & 1987 \\
Worthen Banking Corp. & Arkansas & 1989 \\
Zions Bancorp & Utah & 1984
\end{tabular}

Source: Golembe and Holland (1986) and Amel (1991).

CEO's salary and bonus in the current year as our proxy for total salary and bonus. Our results do not change significantly when we incorporate data (obtained from Forbes) on other payments such as long-term compensation plans, thrift plan contributions, company-paid health insurance plans, and restricted stock awards that are vested or released from restrictions. Because this information is not available for our full sample, however, we restrict our analysis to salary and bonus.

To test whether the sensitivity of CEO pay to performance changes due to deregulation, we begin by first investigating the sensitivity of salary and bonus to performance. As this is not readily observable, we estimate a fixed effects model to capture the sensitivity of salary and bonus to performance. ${ }^{3}$ Our finding of higher levels of salary and bonus in deregulated banking environments is traceable in part to a time trend, since most of the states were without interstate banking in 1980 but had converted to interstate banking by 1989 . We allow for this possibility by estimating a model in which the intercept term includes not only bank-specific effects but year dummies. To examine the

\footnotetext{
${ }^{3}$ Given the longitudinal nature of our data, we test if panel regressions (fixed effects or random effects models) are more efficient to use in our sample than pooling the data and using ordinary least squares. Specifically, we perform an $F$-test on the restriction of equal intercepts at the group level. This restriction is rejected at the $5 \%$ level for all our specifications, suggesting that the fixed effects model does better than running ordinary least squares on the pooled data. We also conduct Breusch and Pagan's (1980) Lagrange multiplier test and find that the random effects model also does better than ordinary least squares on the pooled data. We test which of these two panel estimation techniques (fixed effects or random effects) we should use by conducting Hausman and Taylor's (1981) specification test. Using the Wald criterion, they suggest that the covariance of an efficient estimator with its difference from an inefficient estimator is zero. We find evidence in support of the fixed effects procedure over the random effects procedure. Accordingly, we always use the fixed effects technique.
} 
possible effects of bank deregulation on the sensitivity of salary and bonus to performance, we include a proxy for the relaxation of interstate entry barriers. A dummy variable assumes the value of unity if the state in which the bank is located has deregulated very restrictive interstate banking laws. Such states would allow participation in interstate regional compacts, or allow their banks to be acquired by out-of-state banks, or permit some form of nationwide banking. Values for these interstate variables are not constant over the ten-year period studied, as many states moved toward less restrictive regulation. We also create an interaction variable between performance and interstate deregulation. As explained in Section 2, we expect the signs of the deregulation variables to be positive under the managerial talent hypothesis.

To estimate the sensitivity of options to performance, we calculate the percentage of total equity on which the CEO is granted options and then test whether deregulation significantly changes this percentage. We also estimate the sensitivity of the CEO's equity ownership to performance by calculating the percentage of total equity that a CEO owns and then testing whether deregulation affects this percentage in a manner consistent with the managerial talent hypothesis.

As in Jensen and Murphy (1990a), performance is measured by shareholder wealth, defined as the stock returns earned during the year multiplied by the price at the beginning of the year multiplied by the number of shares outstanding. We expect shareholder wealth to be positively related to compensation.

To control for possible bank size effects, we include the asset size of the bank in the current year. By including this measure as an independent variable in the panel regressions, we can test whether fast-growing banks have CEOs with higher levels of compensation. Consequently, to test whether, ceteris paribus, large banks have CEOs with higher levels of compensation, we regress the estimated bank-specific effects on the average asset size of a bank.

\section{Empirical tests and results}

We begin our empirical tests by examining whether the level of CEO compensation increases following the relaxation of restrictive interstate banking legislation. Sample averages of the dollar value of salary and bonus and the value of stock options granted before and after regulatory liberalization are presented in Table 2 .

We find that the dollar value of salary and bonus, and also the dollar value of options granted, increase significantly after deregulation. These increases are statistically significant, providing preliminary evidence that interstate banking deregulation affects the level of compensation, consistent with the managerial talent hypothesis. 
Table 2

Sample averages of components of CEO pay and equity holdings, and tests for differences in these components and equity holdings before and after interstate banking was legislated; 147 banks, 1980-1989, in thousands of 1989 dollars unless explicitly stated

\begin{tabular}{|c|c|c|c|}
\hline $\begin{array}{l}\text { Average compensation components } \\
\text { and equity holdings }\end{array}$ & $\begin{array}{l}\text { Before } \\
\text { interstate } \\
\text { banking }\end{array}$ & $\begin{array}{l}\text { After } \\
\text { interstate } \\
\text { banking }\end{array}$ & $\begin{array}{l}t \text {-statistic for } \\
\text { differences }\end{array}$ \\
\hline Salary and bonus & 393.35 & 551.80 & $(-10.32)^{a}$ \\
\hline Options granted & 133.52 & 190.28 & $(-2.09)^{b}$ \\
\hline $\begin{array}{l}\text { Percentage of total equity on which } \\
\text { CEO is granted options }\end{array}$ & $0.09 \%$ & $0.12 \%$ & $(-2.21)^{\mathrm{b}}$ \\
\hline $\begin{array}{l}\text { Percentage of total equity held } \\
\text { by CEO }\end{array}$ & $1.79 \%$ & $1.97 \%$ & $(-1.98)^{\mathfrak{b}}$ \\
\hline
\end{tabular}

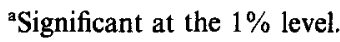

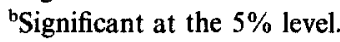

To consider the managerial talent hypothesis more carefully, we estimate panel regressions of compensation on managerial performance (that is, shareholder wealth) and interstate banking deregulation. In panel A of Table 3, we control for bank-specific omitted variables. We find the coefficient on shareholder wealth to be positive and statistically significant at the $1 \%$ level, consistent with Jensen and Murphy (1990a), Barro and Barro (1992), Murphy (1985), and Houston and James (1992). This coefficient of 0.129 corresponds to an increase of 12.9 cents in a bank CEO's salary and bonus per $\$ 1,000$ increase in bank shareholders' wealth, consistent with the Jensen and Murphy (1990a) and Houston and James (1992) findings of a change of 1.35 cents and 15 cents, respectively, in a firm CEO's salary and bonus per $\$ 1,000$ increase in firm performance. We then include the dummy variable for interstate banking deregulation as a regressor, and find that it is positively related to compensation at the $1 \%$ significance level. This finding of higher levels of compensation under deregulation is consistent with the managerial talent hypothesis. We also estimate a panel regression with salary, bonus, and options as our dependent variable, and find that shareholder wealth has a larger estimated coefficient and is positively related to compensation. The interstate banking deregulation variable is still positively related to compensation. These results show strong support for the managerial talent hypothesis, wherein restrictive banking environments have CEOs with lower levels of compensation. Finally, we construct an interaction variable between shareholder wealth and the dummy for deregulating restrictive interstate banking laws. We find this interaction variable to be insignificant, suggesting that deregulation does not affect the sensitivity of salary and bonus to bank performance. Including bank asset size does not change any of our results (although the statistical significance of the estimated asset 
Table 3

Bank-specific (fixed-effects) estimation of the effect of interstate regulation on the level of CEO compensation; sample of 147 banks (including banks with CEO changes), 1980-1989

The dependent variable is CEO compensation, defined as the dollar value of salary and bonus and expressed in thousands of dollars. Shareholder wealth is defined as the stock returns earned during the year, times the price at the beginning of the year, times the number of shares outstanding, and is expressed in millions of dollars. The asset size of the bank is expressed in hundreds of millions of dollars. All monetary variables are reported in constant (1989) dollars ( $t$-statistics are in parentheses).

Dependent variable is salary and bonus

Regressors

(1)

(2)

(3)

Panel A: Controlling for bank-specific omitted variables

Shareholder wealth

0.129

0.118

0.124

Dummy equal to unity for deregulating restrictive $(6.323)^{\mathrm{a}}$

$(6.289)^{\mathrm{a}}$

$(6.616)^{\mathrm{a}}$ interstate laws

178.00

169.32

$(17.779)^{\mathrm{a}}$

$(16.634)^{\mathrm{a}}$

(Shareholder wealth) $\times$ (Dummy equal to unity for deregulating restrictive interstate laws)

0.007

0.001

$(0.140)$

(0.001)

Asset size

$-$

0.115

$(3.977)^{2}$

$\bar{R}^{2}$

0.566

0.676

0.681

Panel B: Controlling for bank-specific omitted variables and year effects (estimated year effects not reported)

\begin{tabular}{|c|c|c|c|}
\hline Shareholder wealth & $\begin{array}{c}0.099 \\
(5.724)^{\mathrm{a}}\end{array}$ & $\begin{array}{l}0.101 \\
(5.449)^{\mathrm{a}}\end{array}$ & $\begin{array}{c}0.103 \\
(5.608)\end{array}$ \\
\hline $\begin{array}{l}\text { Dummy equal to unity for deregulating restrictive } \\
\text { interstate laws }\end{array}$ & - & $\begin{array}{l}21.78 \\
(1.686)^{\mathfrak{c}}\end{array}$ & $\begin{array}{l}21.33 \\
(1.679)^{\mathrm{c}}\end{array}$ \\
\hline $\begin{array}{l}\text { (Shareholder wealth) } \times \text { (Dummy equal to unity for } \\
\text { deregulating restrictive interstate laws) }\end{array}$ & - & $\begin{array}{c}0.014 \\
(0.317)\end{array}$ & $\begin{array}{c}0.015 \\
(0.359)\end{array}$ \\
\hline Asset size & - & - & $\begin{array}{c}0.056 \\
(2.038)^{\mathrm{b}}\end{array}$ \\
\hline $\bar{R}^{2}$ & 0.730 & 0.731 & 0.732 \\
\hline
\end{tabular}

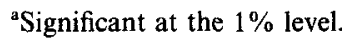

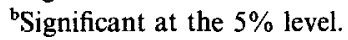

'Significant at the $10 \%$ level.

size coefficient suggests that CEOs of more rapidly growing banks have more generous salary and bonus packages).

Higher levels of compensation in deregulated banking environments are traceable in part to a time trend, since most of the states were without interstate banking in 1980 but had converted to interstate banking by 1989 . We allow for 
this possibility by estimating a model in which the intercept term includes year dummies as well as bank-specific effects. As shown in panel B of Table 3, the results do not change dramatically, although the standard errors associated with our estimated coefficients are larger.

In summary, the results of Table 2 and Table 3 offer strong evidence that interstate deregulation increases the level of CEO compensation as predicted by the managerial talent hypothesis. We now turn our attention to whether CEO turnover changes before and after deregulation. The results of this analysis are given in Table 4.

We begin by examining the 125 banks for which CEO data are completely available. From this sample we eliminate nine banks in which CEO changes occurred both in the three years before and the three years after deregulation, leaving us with a sample of 116 banks in which to examine CEO turnover. There were four banks whose CEOs changed in the year in which deregulation was instituted, two of which experienced deregulation in the first six months of the relevant year and two in the last six months of the relevant year; this even split suggests that our results are not biased by banks whose CEOs changed in the year of deregulation. We find that 21 banks experienced changes in CEO in the three years before interstate banking was legislated, resulting in a turnover rate

Table 4

CEO turnover before and after interstate banking was legislated; 147 banks, 1980-1989

Total number of banks in sample

Banks for which data on the number of years the bank executive has been CEO are missing

Total number of banks for which data on the number of years executive has been CEO are available

Number of banks for which CEO changes occurred both in the three years before and the three years after interstate legislation was introduced

Total number of banks used to examine CEO turnover

Number of banks for which CEO changes occurred in the three years after interstate legislation was introduced

Number of banks for which CEO changes occurred in the three years before interstate legislation was introduced

Number of banks for which there were no CEO changes

Turnover ratio in the three years after interstate legislation was introduced

Turnover ratio in the three years before interstate legislation was introduced

${ }^{a}$ Turnover ratio is defined as the percentage of banks in which CEO changes occurred divided by the total number of banks used to examine CEO turnover. 
of $18.1 \%$. We assume this rate to be the 'normal' turnover rate due to factors other than the relaxation of restrictive interstate regulation. The number of banks whose CEOs changed in the three years after interstate banking deregulation jumps to 40 , an increase of $90.5 \%$. The higher turnover ratio of $34.5 \%$ also confirms that turnover increases after deregulation, in support of the managerial talent hypothesis. Since interstate banking deregulation occurred at different periods for the banks in the sample, the possibility that increased turnover is due entirely to a macroeconomic trend is remote.

The tests describcd thus far use bank effects to control for omitted variables that are specific to the bank. This procedure ignores the fact that different CEOs might have managed the bank over the sample period; that is, the calculated mean differences in compensation abstract from the differences between banks with the same CEO during the sample period and banks with different CEOs during the sample period. Accordingly, we create a subsample of banks whose CEOs were present throughout the sample period to ensure that the change in the new CEO's compensation and equity holdings from that of his or her predecessor has no significant impact on our results. Accordingly, we use a sample in which there were no $\mathrm{CEO}$ changes during our sample period. This allows us to obtain a sufficient number of years for each CEO, and produces a sample of 55 bank CEOs. We reestimate the specifications reported in Table 3, the results of which are given in Table 5. These results suggest that shareholder wealth is still positively related to salary and bonus. ${ }^{4}$ In addition, deregulation of restrictive interstate banking laws is positively and significantly related to the level of compensation in this sample of banks with no CEO changes. The interaction variable remains insignificant. Introducing year dummies changes none of our results.

We also examine the effect of interstate deregulation on the pay-performance relationship. Given that the incentives provided by equity holdings and options are mostly observable, we need not estimate models to find their sensitivity to bank performance (as opposed to the sensitivity of bank performance to salary and bonus, which is not observable). Accordingly, we begin by examining the full sample of banks, which includes banks with (and without) CEO changes during the 1980s. The results are presented in panel A of Table 6. Given that the interaction variable between shareholder wealth and the deregulation dummy was statistically insignificant when examining salary and bonus in panel B of

\footnotetext{
${ }^{4}$ The evidence that compensation levels increase after deregulation even for incumbent CEOs supports the hypothesis of Joskow, Rose, and Shepard (1993) that a lower compensation level in regulated industries reflects political constraints on CEO compensation. However, corroborating the argument of Peltzman (1993), we find no evidence of CEOs moving from banks in regulated states to banks in unregulated states, as would be likely if there was a well-functioning managerial labor market. To resolve this issue conclusively requires additional research.
} 
Table 5

Bank-specific (fixed-effects) estimation of the effect of interstate regulation on the level of CEO compensation; 55 banks without any CEO changes, 1980-1989

The dependent variable is CEO compensation, defined as the dollar value of salary and bonus and expressed in thousands of dollars. Shareholder wealth is defined as the stock returns earned during the year, times the price at the beginning of the year, times the number of shares outstanding, and is expressed in millions of dollars. The asset size of the bank is expressed in hundreds of millions of dollars. All monetary variables are reported in constant (1989) dollars ( $t$-statistics are in parentheses).

Dependent variable is salary and bonus

Regressors

(1)

(2)

(3)

Panel A: Controlling for bank-specific omitted variables

Shareholder wealth

\begin{tabular}{lcc}
0.125 & 0.114 & 0.113 \\
$(3.114)^{\mathrm{a}}$ & $(3.351)^{\mathrm{a}}$ & $(3.326)^{\mathrm{a}}$ \\
- & 196.64 & 187.20 \\
& $(13.147)^{\mathrm{a}}$ & $(12.139)^{\mathrm{a}}$ \\
- & 0.108 & 0.097 \\
& $(1.170)$ & $(1.059)$ \\
- & - & 0.112 \\
& & $(2.331)^{\mathrm{b}}$ \\
0.584 & 0.715 & 0.717 \\
\hline
\end{tabular}

Panel B: Controlling for bank-specific omitted variables and year effects (estimated year effects not reported)

Shareholder wealth

$\begin{array}{llc}0.089 & 0.086 & 0.086 \\ (2.717)^{\mathrm{a}} & (2.593)^{\mathrm{a}} & (2.600)^{\mathrm{a}} \\ - & 44.84 & 42.99 \\ & (2.038)^{\mathrm{b}} & (1.95)^{\mathrm{c}} \\ - & 0.043 & 0.042 \\ & (0.491) & (0.484) \\ - & & 0.051 \\ & & (1.115) \\ 0.763 & 0.764 & 0.764\end{array}$

Dummy equal to unity for deregulating restrictive interstate laws

(Shareholder wealth) $\times$ (Dummy equal to unity for deregulating restrictive interstate laws)

Asset size

0.764

0.764

${ }^{a}$ Significant at the $1 \%$ level.

'Significant at the $5 \%$ level.

'Significant at the $10 \%$ level.

Table 3, the pay-performance sensitivity remains approximately the same before and after interstate deregulation.

The percentage of total equity on which a CEO is granted options is $0.09 \%$ before deregulation and $0.12 \%$ after deregulation (see Table 2). As in Jensen and 
Murphy (1990a) and Sloan (1993), we use 60 cents as the average increase in Black-Scholes option values for a $\$ 1$ increase in stock price. This approximation works well for at-the-money option grants and for reasonable estimates of volatilities, interest rates, and dividend yields. Using this approximation, the wealth of a CEO who holds $0.09 \%$ of the total equity in the bank increases by $\$ 0.54$ for a $\$ 1,000$ increase in shareholder wealth. The corresponding increase in CEO wealth after deregulation is $\$ 0.72$ for a $\$ 1,000$ increase in shareholder wealth. The sensitivity of the value of options granted to shareholder wealth increases significantly following deregulation.

Next, we turn our attention to the incentives provided by the equity holdings of the CEO. We calculate the percentage of total equity held by the CEO before and after deregulation. Jensen and Murphy (1990a) show that the distribution of CEO equity holdings is extremely skewed, suggesting the use of the median percentage of equity holdings rather than the average percentage of equity holdings. Accordingly, we estimate the median percentage of total equity held by the CEO before deregulation to be $0.37 \%$. The median percentage of total equity held by the CEO after deregulation is estimated to be $0.49 \%$. These estimates translate to a $\$ 3.70$ increase in CEO wealth for a $\$ 1,000$ increase in shareholder wealth before deregulation, and a $\$ 4.90$ increase in CEO wealth for a $\$ 1,000$ increase in shareholder wealth after deregulation. Consequently, the total pay-performance sensitivity before deregulation is $\$ 4.34$ for a $\$ 1,000$ increase in shareholder wealth and $\$ 5.72$ for a $\$ 1,000$ change in shareholder wealth after deregulation. This increase in pay-performance sensitivity after deregulation is consistent with the managerial talent hypothesis.

The sample examined above includes banks which had one or more CEOs during the 1980s. Again, we reestimate our pay performance sensitivities for the sample of banks with no CEO changes. The results are presented in panel $B$ of Table 6. Once again, the sensitivity of salary and bonus to performance is not affected by deregulation. We calculate the percentage of total equity held by the CEO before and after deregulation to be $0.07 \%$ and $0.09 \%$, respectively. These results suggest an increase of $\$ 0.42$ in CEO wealth due to options granted before deregulation and an increase of $\$ 0.54$ in CEO wealth due to options granted after deregulation (each estimated for an increase of $\$ 1,000$ in shareholder wealth). We estimate the median percentage of total equity held by the CEO before deregulation to be $0.53 \%$ and the median percentage of total equity held by the CEO after deregulation to be $0.69 \%$. These estimates translate to a $\$ 5.30$ increase in CEO wealth for a $\$ 1,000$ increase in shareholder wealth before deregulation and a $\$ 6.90$ increase in CEO wealth for a $\$ 1,000$ increase in shareholder wealth after deregulation. The total pay-performance sensitivity before deregulation is $\$ 5.81$ for a $\$ 1,000$ increase in shareholder wealth and increases after deregulation to $\$ 7.53$ for a $\$ 1,000$ change in shareholder wealth. Thus, we find an increased pay-performance sensitivity after deregulation, consistent with the managerial talent hypothesis. 
Table 6

Pay-performance sensitivity; change in CEO wealth for a $\$ 1,000$ change in shareholder wealth

\begin{tabular}{llll}
\hline Before & After & Differences in \\
interstate & interstate & sensitivity due \\
banking & banking & to deregulation
\end{tabular}

Panel A: Full sample of 147 banks

$\begin{array}{llll}\text { Salary and bonus }^{\mathrm{a}} & \$ 0.10 & \$ 0.10 & \$ 0.00 \\ \text { Options granted }^{\mathrm{b}} & \$ 0.54 & \$ 0.72 & \$ 0.18 \\ \text { Median equity holdings }^{\mathrm{c}} & \$ 3.70 & \$ 4.90 & \$ 1.20 \\ \text { Total pay-performance sensitivity } & \$ 4.34 & \$ 5.72 & \$ 1.38\end{array}$

Panel B: Restricted sample of 55 banks without CEO changes

$\begin{array}{llll}\text { Salary and bonus }^{\mathrm{d}} & \$ 0.09 & \$ 0.09 & \$ 0.00 \\ \text { Options granted }^{\mathrm{e}} & \$ 0.42 & \$ 0.54 & \$ 0.12 \\ \text { Median equity holdings }^{\mathrm{f}} & \$ 5.30 & \$ 6.90 & \$ 1.60 \\ \text { Total pay-performance sensitivity }^{\text {Tol }} & \$ 5.81 & \$ 7.53 & \$ 1.72\end{array}$

${ }^{a}$ Taken from the results of panel $B$ in Table 3. Given that the interaction term between shareholder wealth and the deregulation dummy is statistically insignificant, the pay-performance sensitivity remains the same before and after interstate banking deregulation.

'The percentage of total equity on which the CEO is granted options on is taken from Table 2 . As in Jensen and Murphy (1990a) and Sloan (1993), we use 60 cents as the average increase in the Black-Scholes option values for a corresponding dollar increase in stock prices.

'Estimated for the sample of 147 banks.

${ }^{d}$ Taken from the results of panel B in Table 5. Given that the interaction term between shareholder wealth and the deregulation dummy is statistically insignificant, the pay-performance sensitivity remains the same before and after interstate banking deregulation.

'The percentage of total equity on which the CEO is granted options on is estimated for the sample of 55 banks. As in Jensen and Murphy (1990a) and Sloan (1993), we use 60 cents as the average increase in the Black-Scholes option values for a corresponding dollar increase in stock prices.

${ }^{\mathrm{f}}$ Estimated for the sample of 55 banks.

To summarize, we find evidence that higher levels of compensation, higher turnover, and a greater pay-performance sensitivity accompany the deregulation of restrictive interstate banking legislation, consistent with the managerial talent hypothesis. These results are inconsistent with the predictions of the risk-differential hypothesis described in Section 3.

\subsection{Examining the differential impact of deregulation on banks without CEO changes and banks with CEO changes}

Under a strict interpretation of the managerial talent hypothesis, higher levels of CEO compensation and a greater pay-performance relationship are used to 
attract executives with greater management skills. Consequently, one would expect higher levels of compensation and a larger pay-performance relationship following deregulation for new CEOs than for incumbent CEOs (i.e., those who remained as chief executives of their banks). Of course, incumbent CEOs could experience higher levels of compensation and a greater pay-performance relationship on account of the increased complexity of their job under the deregulated environment; we do not necessarily expect the levels of compensation and the pay-performance relationship for incumbent CEOs to remain constant. Our analysis thus far shows that pay-performance sensitivity increases under deregulation, both for banks with CEO changes and for banks with no CEO changes, although the magnitude of the increase differs across the two samples. Hence, we compare the differences in the pay-performance sensitivity due to deregulation in the last column of Table 6 .

We find no significant differences in the sensitivity of salary and bonus to performance (due to deregulation) between the sample with CEO changes and the sample without CEO changes. However, we observe that the increase in the sensitivity in the value of options granted is higher in the sample that includes CEO changes than in the sample without CEO changes. This result seems reasonable as the sample with CEO changes includes new CEOs who have to be given more options in order to 'catch up' to the stock ownership levels of the previous CEO. We next examine the sensitivity of median equity holdings to bank performance. We find that the increase in the sensitivity of median equity holdings (due to deregulation) is greater in the sample without CEO changes than in the sample with CEO changes. One possible interpretation of this result is that in the sample without CEO changes, incumbent CEOs build up their equity ownership over their tenure and increase their holdings significantly after deregulation. By contrast, in the sample with CEO changes, new CEOs have not yet acquired much ownership in their first year, so that equity holdings are less than those of the previous CEO.

In summary, our results suggest that pay-performance sensitivity increases for banks with and without CEO changes. However, the sample that includes banks with CEO changes has a smaller increase in the sensitivity of equity holdings because new CEOs have lower equity holdings than their predecessors. Conversely, the sample of banks with no CEO changes has less of an increase in the sensitivity of the value of options because new CEOs are granted larger amounts of options in order to build up their equity holdings.

\subsection{Effect of asset size on CEO wealth}

To test whether CEO wealth is related to asset size, other things equal, we obtain the bank-specific effects from two specifications. The first specification regresses shareholder wealth on salary and bonus and the second specification regresses shareholder wealth on salary, bonus, and options. We choose 
Table 7

Ordinary least squares regression of the fixed effects on bank asset size

The dependent variables are the estimated bank-specific fixed effects, obtained by regressing salary and bonus in the first row, and salary, bonus, and options in the second row of each panel. The independent variable is the average asset size of the bank, and is expressed in hundreds of millions of dollars. All monetary variables are reported in constant (1989) dollars ( $t$-statistics are in parentheses).

\begin{tabular}{lccc}
\hline Specification & Constant & Asset size & $\bar{R}^{2}$ \\
\hline Panel A: Full sample of 147 banks & & & 0.389 \\
Salary and bonus & 36.620 & 1.011 & \\
& $(10.075)^{\mathrm{a}}$ & $(27.196)^{\mathrm{a}}$ & 0.358 \\
Salary, bonus, and options & 52.369 & 1.271 & \\
& $(9.410)^{\mathrm{a}}$ & $(23.819)^{\mathrm{a}}$ & \\
\hline Panel B: Restricted sample of 55 banks without CEO changes & & 0.499 \\
Salary and bonus & 33.216 & 1.938 & \\
& $(6.367)^{\mathrm{a}}$ & $(21.922)^{\mathrm{a}}$ & 0.457 \\
Salary, bonus, and options & 45.301 & 2.578 & $(19.047)^{\mathrm{a}}$ \\
\end{tabular}

aSignificant at the $1 \%$ level.

specifications in which asset size does not already appear as a regressor in order to avoid any spurious correlation. The intercept term (the fixed effects) obtained from the full sample which includes banks with CFO changes (panel A) or from the restricted sample which includes banks only without CEO changes (panel B) is then regressed on the average asset size of a bank during the sample period. The results, given in Table 7, provide strong evidence that asset size is related to compensation, ceteris paribus, whether compensation is defined as salary and bonus or salary, bonus, and options. These results are consistent with the hierarchial hypothesis of Rosen (1982) in which larger firms have senior executives whose managerial productivity of actions is magnified over a bigger scale of operations.

\section{Conclusions}

The business press and the legislative process have focused much attention on the 'excessive' pay of CEOs. Indeed, there have been many proposals to introduce regulation limiting CEO pay. In contrast, Jensen and Murphy (1990a, 1990b) have observed that the lack of any large correlation between pay and performance can be attributed to some form of implicit regulation (e.g., public or 
private political forces that effectively truncate the upper tail of the compensation distribution which should be awarded to exceptional managers). They suggest that to align managerial incentives with shareholders' interests, caps on managerial salaries should be eliminated and the sensitivity of compensation to performance should be enhanced to reward the better performing managers.

Using the banking industry, in which historical interstate banking regulations allow relatively straight-forward identification of markets for corporate control with varying degrees of potential competition, we examine panel data on 147 banks over the decade of the 1980s. We find both higher levels of CEO compensation and a more pronounced compensation-performance relationship when interstate banking is permitted than when interstate banking is not permitted. This result is robust to controlling for omitted variables at the bank-specific level. In addition, we find that CEO turnover increases substantially after state-level deregulation of interstate banking. While such results must be interpreted with caution, they are consistent with the idea that restricting pay levels of chief executive officers reduces the effectiveness of a well-functioning managerial labor market and its associated pay structure in attracting talented managers to challenging careers. We also find evidence that the size of the bank is positively related to the level of compensation.

\section{References}

Amel, Dean F., 1991, State laws affecting commercial bank branching, multibank holding company expansion, and interstate banking, Working paper (Board of Governors of the Federal Reserve System, Washington, DC).

Antle, Rick and Abbie Smith, 1986, An empirical investigation of the relative performance evaluation of corporate executives, Journal of Accounting Research 24, 1-32.

Barro, Jason R. and Robert J. Barro, 1990, Pay, performance and turnover of bank CEOs, Journal of Labor Economics 8, 448-481.

Berle, Adolf A. and Gardiner C. Means, 1932, The modern corporation and private property (Macmillan, New York, NY).

Black, Fischer and Myron Scholes, 1973, The pricing of options and corporate liabilities, Journal of Political Economy 81, 637-659.

Breusch, T.S. and A.R. Pagan, 1980, The Lagrange multiplier test and its application to model specification in econometrics, Review of Economic Studies 47, 239-253.

Ciscell, David H. and Thomas M. Carroll, 1980, The determinants of executive salaries: An econometric survey, Review of Economics and Statistics 62, 7-13.

Coughlan, Anne T. and Ronald M. Schmidt, 1985, Executive compensation, management turnover and firm performance, Iournal of Accounting and Economics 7, 43-66.

Crawford, Anthony J., John R. Ezzell, and James A. Miles, 1993, Bank CEO pay-performance relations and the effects of deregulation, Working paper (Pennsylvania State University, University Park, PA).

Dunlevy, James A., 1985, Econometric issues in the analysis of executive compensation, Review of Economics and Statistics 67, 171-174.

Gibbons, Robert and Kevin J. Murphy, 1990, Relative performance evaluation for chief executive officers, Industrial and Labor Relations Review 43, 30-51. 
Golembe, Carter H. and David S. Holland, 1986, Federal regulation of banking, 1986-87 (Golembe Associates, Washington, DC).

Greene, William H., 1993, Econometric analysis (Macmillan, New York, NY).

Hausman, J. and W. Taylor, 1981, Panel data and unobservable individual effects, Econometrica 49. $1377-1398$.

Hermalin, Benjamin E. and Michael S. Weisbach, 1988, The determinants of board composition, Rand Journal of Economics 19, 589-606.

Houston, Joel and Christopher James, 1992, Managerial ownership, turnover and risk-taking in banking, Working paper (University of Florida, Gainesville, FL).

Hsiao, Cheng, 1986, Analysis of panel data (Cambridge University Press, New York, NY).

Hubbard, R. Glenn, 1994, Money, the financial system, and the economy (Addison-Wesley, Reading, MA).

Jensen, Michael C., 1986, Agency costs of free cash flow, corporate finance and takeovers, American Economic Review 76, 323-329.

Jensen, Michael C. and William H. Meckling, 1976, Theory of the firm: Managerial behavior, agency costs and ownership structure, Journal of Financial Economics 3, 305-360.

Jensen, Michael C. and Kevin J. Murphy, 1990a, Performance, pay and top-management incentives, Journal of Political Economy 98, 225-264.

Jensen, Michael C. and Kevin J. Murphy, 1990b, CEO incentives - it's not how much you pay, but how, Journal of Applied Corporate Finance 3, 36-49.

Joskow, Paul L., Nancy L. Rose, and Andrea Shepard, 1993, Regulatory constraints on CEO compensation, Brookings Papers on Economic Activity (Microeconomics), 1-72.

Kostiuk, Peter F., 1989, Firm size and executive compensation, Journal of Human Resources 25, 90-105.

Murphy, Kevin J., 1985, Corporate performance and managerial remuneration, Journal of Accounting and Economics 7, 11-42.

Murphy, Kevin J., 1986, Incentives, learning, and compensation: A theoretical and empirical investigation of managerial labor contracts, Rand Journal of Economics 17, 59-76.

Murphy, Kevin J. and Jerold L. Zimmerman, 1991, Financial performance over CEO careers: An empirical investigation, Working paper (University of Rochester, Rochester, NY).

Norcen, Eric W. and Mark A. Wolfson, 1981, Equilibrium warrant pricing models and accounting for stock options, Journal of Accounting Research 19, 384-398.

Peltzman, Sam, 1993, Comment, Brookings Papers on Economic Activity (Microeconomics), 63-66.

Rose, Nancy L. and Andrea Shepard, 1994, Firm diversification and CEO compensation: Managerial ability or executive entrenchment?, NBER working paper no. 4723 .

Rosen, Sherwin, 1982, Authority, control, and the distribution of earnings, Bell Journal of Economics 13, 311-323.

Rosen, Sherwin, 1990, Contracts and the market for executives, NBER working paper no. 3542.

Shleifer, Andrei and Robert W. Vishny, 1988, Value maximization and the acquisition process, Journal of Economic Literature 2, 7-20.

Simon, Herbert A., 1957, The compensation of executives, Sociometry 20, 32-35.

Sloan, Richard G., 1993, Accounting earnings and top executive compensation, Journal of Accounting and Economics 16, 55-100.

Smith, Clifford W. and Ross L. Watts, 1992, The investment opportunity set and corporate financing, dividend and compensation policies, Journal of Financial Economics 32, 263-292.

Warner, Jerold B., Ross L. Watts, and Karen H. Wruck, 1988, Stock prices and top management changes, Journal of Financial Economics 20, 461-492.

Weisbach, Michael S., 1988, Outside directors and CEO turnover, Journal of Financial Economics 20, 431-460. 